\title{
In vitro Model of the Blood-brain Barrier Established by Co-culture of Primary Sheep Cerebral Microvascular Endothelial and Astrocyte Cells
}

\author{
Jingjing REN ${ }^{1}$ Mingwei YANG ${ }^{1}$ Genqiang YAN 1 \\ Jianjun JIANG 's Pengyan WANG 's
}

${ }^{1}$ College of Animal Science and Technology, Shihezi University, Shihezi, Xinjiang, 832003, P. R. CHINA

Article Code: KVFD-2017-19003 Received: 15.11.2017 Accepted: 22.03.2018 Published Online: 23.03.2018

How to Cite This Article

Ren J, Yang M, Yan G, Jiang J, Wang P: In vitro model of the blood-brain barrier established by co-culture of primary sheep cerebral microvascular endothelial and astrocyte cells. Kafkas Univ Vet Fak Derg, 24 (3): 379-386, 2018. DOI: 10.9775/kvfd.2017.19003

\begin{abstract}
Blood-brain barrier (BBB) characteristics are induced and maintained by cross-talk between brain microvessel endothelial cells and neighbouring elements of the neurovascular unit. It plays a primary role in a selective diffusion barrier at the level of the cerebral microvascular endothelium. Here, we have developed and characterized an in vitro model of the blood-brain barrier by seeding primary brain microvascular endothelial cells (BMECs) and astrocyte cells (ACs) from sheep on a polyester Transwell cell culture membrane with 0.4- $\mu \mathrm{m}$ pores, and conducted transepithelial electrical resistance measurements (TEER), leakage tests and assays for the permeability of horseradish peroxidase (HRP). The results of TEER and 4-h leakage assay showed that the new syngeneic BBB model had a characteristic of BBB in vivo. The HRP permeability test showed that the BBB model had good barrier function. Results showed that our model may be a valuable tool in the study of the mechanisms of brain invasion mediated by internalins of Listeria monocytogenes.
\end{abstract}

Keywords: Blood-brain barrier, Astrocytes, Brain microvascular endothelial cells, Co-culture, In vitro BBB model, Sheep

\section{Primer Koyun Serebral Mikrodamar Endotelyal ve Astrosit Hücrelerinin Birlikte Kültüre Edilmesiyle Oluşturulmuş In vitro Kan Beyin Bariyeri Modeli}

Öz

Kan beyin bariyeri beyin mikrodamar endotelyal hücreleri ve nörovasküler birimin komşu elementleri tarafından oluşturulur ve devamlılı̆ı sağlanır. Kan beyin bariyeri serebral mikrovasküler endotel seviyesinde seçici difüzyon bariyeri olarak önemli bir rol oynar. Bu çalışmada 0.4m gözeneğe sahip polyester Transwell hücre kültürü membranına koyun primer beyin microdamar endotel hücreleri ve astrosit hücrelerinin ekimiyle in vitro kan beyin bariyeri oluşturuldu. Karakterizasyonu transepitelyal elektrik dirençölçümleri, sızıntı testleri ve horseradish peroksidaz geçirgenliği testleri ile gerçekleştirildi. Transepitelyal elektrik direnç ölçümleri ve 4-h sızıntı testleri sonuçları yeni oluşturulan singeneik kan beyin bariyeri modelinin in vivo kan beyin bariyeri özelliklerine sahip olduğunu gösterdi. Horseradish peroksidaz geçirgenliği testi yeni oluşturulan kan beyin bariyerinin iyi bariyer fonksiyonlarına sahip olduğunu gösterdi. Elde edilen sonuçlar oluşturulan Listeria monocytogenes internalinleri tarafından oluşturulan beyin invazyonunun mekanizmasının çalışılmasında bu modelin yararlı olabileceğini göstermektedir.

Anahtar sözcükler: Kan beyin bariyeri, Astrositler, Beyin mikrodamar endotelyal hücreleri, Kokültür, In vitro Kan beyin bariyeri modeli, Koyun

\section{INTRODUCTION}

The blood-brain barrier (BBB) is a low-permeability cell system between the central nervous system and circulating blood ${ }^{[1]}$. It acts as a 'physical barrier' because complex tight junctions between adjacent endothelial cells force most molecular traffic to take a transcellular route across the $B B B$, rather than moving paracellularly through the junctions, as in most endothelia ${ }^{[2]}$. The BBB mainly comprises brain microvascular endothelial cells (BMECs), basement membrane, and astrocytic foot, processes. The specific structure and function of the BBB mean it is difficult to replicate in an in vitro model. It is therefore important to establish a model that is as close to the in vivo environment as possible, and can be easily replicated ${ }^{[3]}$. Cell-culture-based models have greatly contributed to our knowledge on the physiology, pathology and pharmacology of the BBB ${ }^{[4,5]}$. Since 1973, when the first in vitro model of the BBB was established by the successful isolation of brain microvessels several models constructed from

\section{8 iletişim (Correspondence)}

篇 +8613309934633 (J. Jiang); Fax +86 09932058721

jiangjianjun7788@163.com (J. Jiang); wwwpy_322@163.com (P. Wang) 
cultured cells have been developed ${ }^{[6,7]}$. Originally, the BBB model is made up of monolayer BMECs, which inadequately represents the structure of the BBB. As the research moves along, researchers found that astrocytes(ACs) could be recognized as regulators of brain endothelial characteristics and functions ${ }^{[8,9]}$. Astrocytes are able to induce among others the formation of interendothelial TJs ${ }^{[10]}$, a fundamental characteristic of the BBB. A great number of currently used in vitro BBB model is composed of coculture of brain endothelial cells with astrocytes ${ }^{[11,12]}$.

Listeria monocytogenes (LM) is a Gram-positive, facultative intracellular bacterium known to cause invasive disease in humans and animals, especially central nervous system (CNS) infections ${ }^{[13,14]}$. LM is a food-borne pathogen that typically enters the host through the gastrointestinal tract, from where it can cross the intestinal epithelium. After dissemination via the lymph and blood stream, LM resides in the liver and spleen, where it multiplies and can lead to the formation of abscesses. LM has the ability to induce meningitis, septicemia, abortion, and mononucleosis ${ }^{[15-17]}$. Although there are many different virulence factors, internalins play a key role for LM in the invasion of non-phagocytic cells ${ }^{[18]}$. Previous studies have shown that the surface proteins InIA and InIB are interdependently required for the invasion by LM in a human model of the bloodcerebrospinal fluid barrier based on human choroid plexus papilloma cells ${ }^{[13]}$.

With the aim to provide a powerful tool for studying the mechanisms of brain invasion mediated by internalins of LM, we established a BBB model in vitro using primitive coculture of sheep BMECs and ACs.

\section{MATERIAL and METHODS}

\section{Animals and Ethical Concerns}

Male or female sheep, aged two months, were obtained from the Lab Animal Research Institute of the China Academy of Medical Sciences and were housed in the facilities with the relatively constant temperature of $25 \pm 2^{\circ} \mathrm{C}$. All animals were treated in strict accordance with the NIH Guide for the Care and Use of Laboratory Animals (NIH Publications No. 80-23) and were approved by the Animal Ethics Committee of Shihezi University (Approval No. AECSU2016-9-S). During the experiment, every effort was made to minimize animal suffering.

\section{Materials}

Dulbecco's modified Eagle's medium (DMEM) and fetal bovine serum (FBS) were purchased from Gibco (Grand Island, NY, USA), and Transwell inserts (aperture $0.4 \mu \mathrm{m}$ ) were purchased from BD Falcon (Franklin Lakes, NJ, USA). All reagents used in the study were purchased from Sigma (Saint Louis, MO, USA). Transendothelial electrical resistance (TEER) was measured using Millicell-ERS (Millipore, Bedford,
MA, USA) and detection of horseradish peroxidase (HRP) was completed using a microplate spectrophotometer (Multiskan MK3, Thermo, Boston, MA, USA).

\section{Isolation of BMECs}

Primary cultures of BMECs were isolated from two-monthold sheep according to a previously described protocol ${ }^{[19]}$, with some modifications. Under aseptic conditions, the pia mater and surface vessels were carefully removed from the forebrains. The cerebral cortex was washed twice with ice-cold D-Hanks' solution before mincing into small pieces of approximately $1 \mathrm{~mm}^{3}$ in DMEM. The pieces were then dissociated by up-and-down strokes with a $15-\mathrm{mL}$ centrifugal tube in DMEM containing collagenase type II $\left(1 \mathrm{mg} / \mathrm{mL}\right.$ ) and then digested in a shaker for $1.5 \mathrm{~h}$ at $37^{\circ} \mathrm{C}$. The cell pellet was separated by centrifugation $(1000 \times \mathrm{g}$, $10 \mathrm{~min}, 25^{\circ} \mathrm{C}$ ), and then centrifuged again in $15 \%$ dextran. Microvascular fractions were separated by centrifugation (3000 $\times \mathrm{g}, 20 \mathrm{~min}, 4^{\circ} \mathrm{C}$ ). Clusters of microvessel endothelial cells obtained in the pellet were further digested with collagenase type II (1 mg/mL) in DMEM for 10-15 $\mathrm{min}$ at $37^{\circ} \mathrm{C}$, collected and washed twice in DMEM before plating on type IV collagen-coated plastic dishes. The cultured BMECs were maintained in DMEM supplemented with $10 \%(\mathrm{v} / \mathrm{v}) \mathrm{FBS}$, basic fibroblast growth factor (bFGF, $1.5 \mathrm{ng} / \mathrm{mL})$, heparin $(100 \mu \mathrm{g} / \mathrm{mL})$, penicillin $(100 \mathrm{U} / \mathrm{mL})$, and streptomycin $(100 \mu \mathrm{g} / \mathrm{mL})$ at $37^{\circ} \mathrm{C}$, in a humidified atmosphere of $5 \% \mathrm{CO}_{2} / 95 \%$ air, for 2 days. On the third day, the cells were seeded at $2 \times 10^{4}$ cells $/ \mathrm{cm}^{2}$ into a new medium, which contained all the components of the medium. The medium was changed once every two days. Pure cultures of BMECs were obtained and stored in liquid nitrogen until used.

\section{Isolation of ACs}

Sheep ACs were isolated according to a previously described protocol, with some modifications ${ }^{[20]}$. The cerebral hemispheres were aseptically removed from sheep. The sheep brains were dissected out and put into precooled D-Hanks' solution. The pia mater and surface vessels were carefully removed from the ice, and the cortical pieces were mechanically dissociated in fresh D-Hanks' solution. The tissue was digested in $0.25 \%$ trypsin for $15 \mathrm{~min}$ at $37^{\circ} \mathrm{C}$, and then AC culture medium (DMEM/F12 supplemented with $20 \%$ FBS) was added to stop digestion. The cells pellet were separated by centrifugation (1000×g, $5 \mathrm{~min})$, resuspended in $A C$ culture medium, and then stationarily incubated for 10 min to remove impurity; this was repeated three times. Dissociated cells were collected by further centrifugation $(1000 \times \mathrm{g}, 5 \mathrm{~min})$ and then resuspended in $A C$ culture medium; the isolated filtrate was filtered through 100 and 200-mesh screens, respectively. The cells were seeded into plastic dishes coated with collagen type IV at $37^{\circ} \mathrm{C}$ with a humidified atmosphere of $5 \% \mathrm{CO}_{2} / 95 \%$ air. The medium was changed once every two days. After reaching $80 \%$ confluence ( $7^{\text {th }}$ day in vitro), the cultures were 
REN, YANG, YAN

JIANG, WANG

horizontally shaken for $18 \mathrm{~h}$ at $37^{\circ} \mathrm{C}(200 \mathrm{r} / \mathrm{min})$ to remove oligodendroglia and microglia. The purified ACs were collected and washed twice with PBS before digesting with $0.25 \%$ trypsin, and then fresh AC culture medium was added to construct an in vitro BBB model.

\section{Construction of In Vitro BBB Models}

To construct the various in vitro models of $B B B$, the ACs were seeded on the bottom side of the collagen-coated polyester membrane at $3 \times 10^{5}$ cells per insert of the Transwell inserts and cultured for 4 days. After 4 days, BMECs were seeded on the inside or upper side of the inserts at $3 \times 10^{5}$ cells per insert and placed in the wells of the 24-well culture plates. Following 10 days of co-culture, the medium was removed and replaced with DMEM/ F12 complete medium, and supplemented with 10\% FBS every two days at $37^{\circ} \mathrm{C}$ with a humidified atmosphere of $5 \% \mathrm{CO}_{2}$, ensuring at the same time that the outside and inside of the Transwell inserts are maintained at the same liquid level (Fig. 1 and Fig. 2). To study the barrier integrity on negative controls, BMECs and ACs were cultured alone on the inserts, respectively. The BMECs and ACs were co-cultured for 10 days and utilized in the experiments below. Co-cultures were independently prepared for each experiment.

\section{Observation of Cell Morphology}

The cells were observed under an inverted microscope to detect the conditions of adherence and growth. Inverted microscope pictures were taken to document the results.

\section{Detection of Transepithelial Electrical Resistance (TEER)}

Permeability changes in the BBB can be detected by changes in TEER, which directly reflects the structural integrity of the $\mathrm{BBB}^{[21]}$. We measured TEER in the co-culture model and single-layer (BMECs or ACs) groups at $1^{\text {th }}$ day, $2^{\text {th }}$ day ${ }^{\prime \prime} 3^{\text {th }}$ day ${ }_{\prime \prime} 4^{\text {th }}$ day ${ }^{\prime \prime} 5^{\text {th }}$ day, and $6^{\text {th }}$ day, after BMECs seeding. The measurements were adjusted for insertion of the Millicell ERS-2 Volt-Ohm Meter (Millipore, Boston, MA, USA) into $70 \%$ ethanol for $15 \mathrm{~min}$. The samples were air-dried for $15 \mathrm{sec}$ and washed in sterilized electrolyte solution. The short and long electrode probes were inserted vertically into the medium inside and outside the Transwell chamber, respectively. TEER of coated, but cell-free filters, was subtracted from the measured TEER values of the models, shown as $\Omega / \mathrm{cm}^{2}$, and the values recorded ${ }^{[22,23]}$.

\section{Liquid Surface Leakage Test}

Once the TEER value was constant, DMEM was added to the interior of the Transwell chamber to maintain a depth of $0.5 \mathrm{~cm}$ between the medium inside and outside of the Transwell. The depths of the media above and below the Transwell chamber were measured again after culturing for $4 \mathrm{~h}$ at $37^{\circ} \mathrm{C}$ under $5 \% \mathrm{CO}_{2}$ condition. If the difference between the liquids remained at $0.4-0.5 \mathrm{~cm}$, this showed that the cells had formed a positive sense barrier ${ }^{[24-27]}$.

\section{In Vitro HRP Permeability Test}

The co-culture model with stable TEER values was chosen to test the permeability of HRP. The DMEM medium

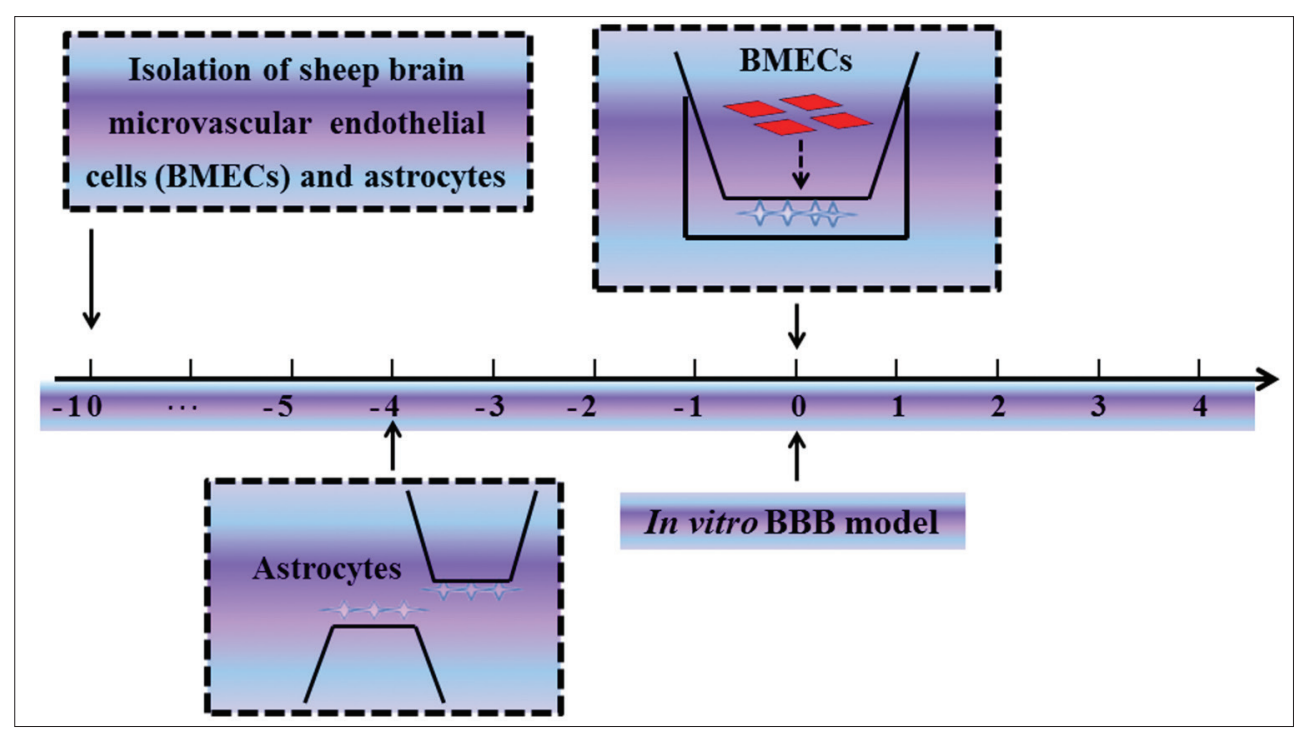

Fig 1. Schematic drawing of the preparation of an in vitro BBB model

Sheep BMECs and ACs were isolated 10 days before the establishment of the co-culture system. To purify the BMECs, the cultured cells are kept in the presence of puromycin for 2 days. First, ACs were seeded on the bottom side of the collagen-coated polyester membrane of the Transwell inserts and allowed to adhere to the wall for 1 day. The day when the endothelial cells were plated and models were established was defined as day zero in vitro (day 0). Hence on day 0 , the BMECs were added to the top of the Transwell inserts. From $1^{\text {th }}$ day, cells are grown in DMEM/F12 culture medium containing 10\% FBS and experiments were then performed on day 10 (not displayed) 


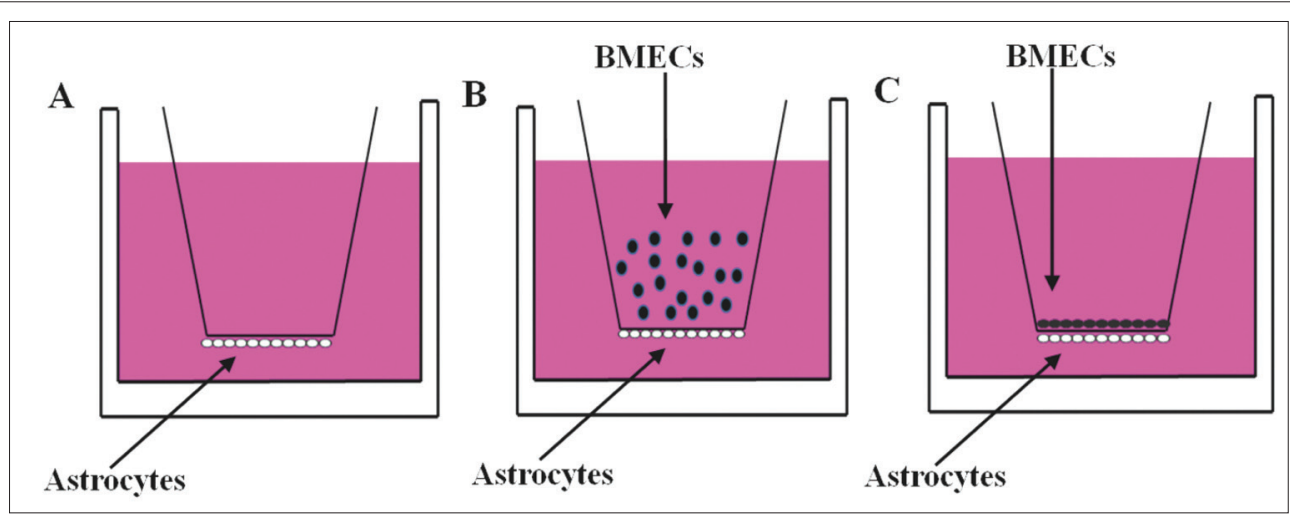

Fig 2. Establishing the in vitro BBB sheep model

(A) ACs $\left(3 \times 10^{5} / \mathrm{mL}\right)$ were seeded on the bottom side of a collagen-coated Transwell chamber. The cells were let to adhere firmly for 1 day, and the Transwell chamber was carefully turned upright and placed in a 24well plate. (B) When ACs reached $80 \%$ confluence, BMECs $\left(3 \times 10^{5} / \mathrm{mL}\right)$ were seeded on the top surface of the Transwell chamber. (C) ACs and BMECs were co-cultured to a high density

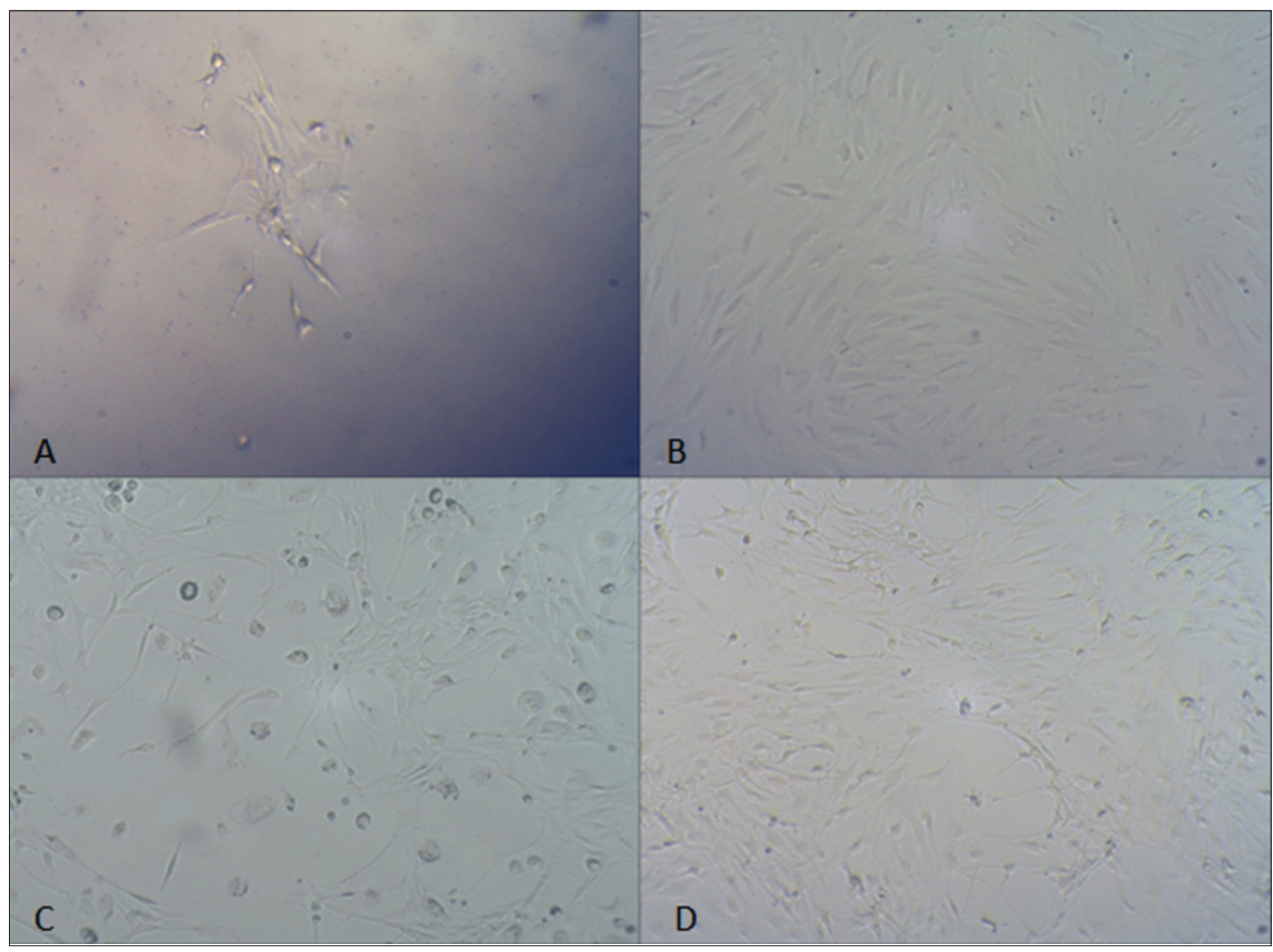

Fig 3. Morphology of primary cultured BMECs and ACs

BMECs under an inverted microscope (100x magnifcation). At 3 days of primary culture (A), BMECs showed single-layer growth. At 10 days (B), cells formed a tight single layer with a typical cobblestone-like appearance. Astrocytes under an inverted microscope (100x magnifcation). At 3 days of primary culture (C), astrocyte bodies were observed with a small number of short processes. At 5 days (D), large astrocyte bodies were observed, with several slender branching processes

from inside Transwell inserts was discarded, $300 \mu \mathrm{L}$ of fresh DMEM/F12 supplemented with $5 \mu \mathrm{M}$ HRP was added to the inside of the Transwell inserts, and 900 $\mu \mathrm{L}$ of fresh DMEM/F12 was added to the well of the 24-well culture plates. This was to make sure the liquid remained at the same level to eliminate the effects of hydrostatic pressure in the permeability of HRP. The plates were then cultured at $37^{\circ} \mathrm{C}$ with a humidified atmosphere of $5 \% \mathrm{CO}_{2}$ for $24 \mathrm{~h}, 50 \mu \mathrm{L}$ of the medium was absorbed at $4^{\text {th }} \mathrm{h}, 8^{\text {th }} \mathrm{h}, 12^{\text {th }} \mathrm{h}, 16^{\text {th }} \mathrm{h}, 20^{\text {th }} \mathrm{h}, 24^{\text {th }} \mathrm{h}$, respectively, and was stored in the well of the 96 -well culture plates at $4^{\circ} \mathrm{C}$. This was followed by adding $50 \mu \mathrm{L}$ of fresh DMEM/F12 into the plates instantly. Finally, 100 $\mu \mathrm{L}$ of HRP substrate (TMB \& $\mathrm{H}_{2} \mathrm{O}_{2}$ ) was added and a color development for $3 \mathrm{~min}$ was performed, then $50 \mu \mathrm{L}$ of 1 $\mathrm{M} \mathrm{H}_{2} \mathrm{SO}_{4}$ was added to end the reaction and measured at $450 \mathrm{~nm}$. The permeability of HRP was calculated from a standard curve: 
Table 1. TEER values in co-culture model group and single-layer groups

\begin{tabular}{|c|c|c|c|}
\hline Time(day) & Single-layer ACs Group & Single-layer BMECs Group & Co-culture Model Group \\
\hline 1 & $239.80 \pm 4.61$ & $247.31 \pm 11.11$ & $302.43 \pm 13.08^{* *}$ \\
\hline 2 & $257.59 \pm 6.96$ & $266.96 \pm 4.73$ & $309.73 \pm 11.28^{* *}$ \\
\hline 3 & $270.27 \pm 10.98$ & $276.70 \pm 16.18$ & $345.50 \pm 13.90^{* *}$ \\
\hline 4 & $280.51 \pm 9.05$ & $286.96 \pm 12.29$ & $343.19 \pm 22.47^{* *}$ \\
\hline 5 & $287.81 \pm 12.31$ & $292.54 \pm 17.93$ & $343.83 \pm 24.64^{* *}$ \\
\hline 6 & $292.07 \pm 12.51$ & $295.80 \pm 16.74$ & $343.78 \pm 14.54^{* *}$ \\
\hline \multicolumn{2}{|r|}{ Data are presented as the means \pm SD (n=6). One-way ANOVA was used for statistical analysis. ${ }^{* *} P<0.05$, vs.single-layer BMECs or ACs group } \\
\hline
\end{tabular}

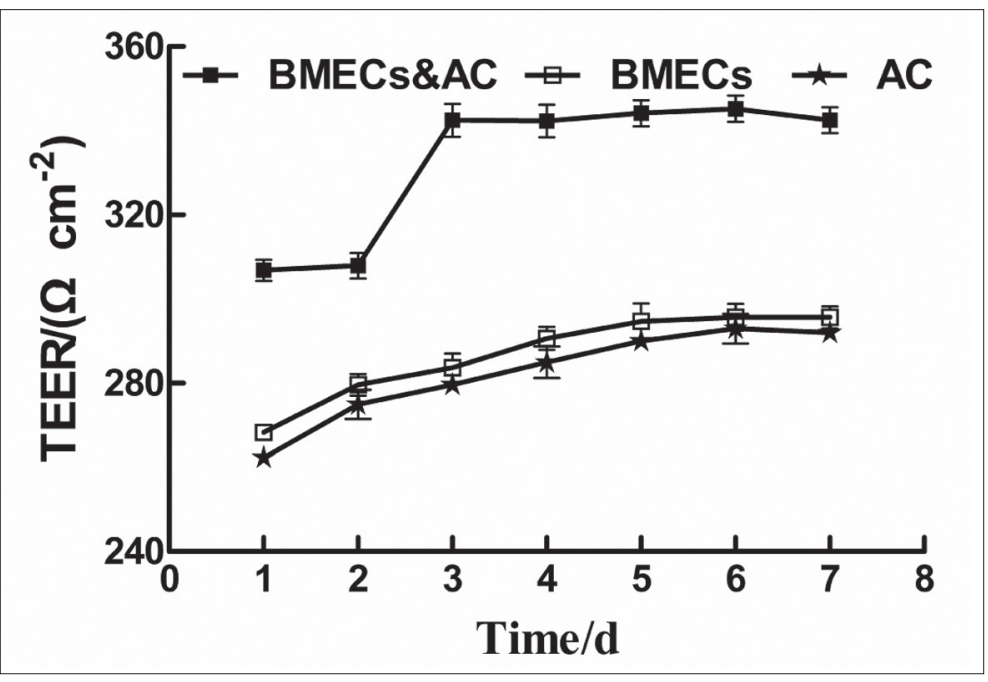

Fig 4. TEER of the different groups at the same time-point

(TEER, expressed as $\Omega / \mathrm{cm}^{2}$ ). All data are presented as means $\pm S D(n=6)$. Statistically significant differences $(P<0.05)$ in TEER are indicated of co-culture model compared to single-layer BMECs group and Single-layer ACs group, respectively. One-way ANOVA was used for statistical analysis. ${ }^{*} \mathrm{P}<0.05$, vs.single-layer BMECs or ACs group. Error bars: SD

cultured ACs had adhered to the wall by the third day of culture, and a small number of short branching processes were observed between the cell bodies (Fig. 3C). At 5 days, all cells had adhered to the wall, and the number of cell bodies had markedly increased, with many slender branching processes stretching between neighboring cells (Fig. 3D).

\section{TEER}

The TEER value in the co-culture model and single layer groups increased with time. The co-culture model was higher than the two single-layer groups as reflected by the TEER values. The resistance of co-culture model increased up to $345.50 \pm 13.90 \Omega / \mathrm{cm}^{2}$ at day 3 , the highest value of the three models tested which significantly differs from other two single-layer groups (Table 1). TEER values plateaued by day 3 in three groups (Fig. 4).

\section{Detection of the Liquid Surface Leakage Test}

When the TEER value was constant, the difference between the depth of the medium inside and outside the Transwell were $0.2 \mathrm{~cm}$ and $0.3 \mathrm{~cm}$ after culturing for $4 \mathrm{~h}$ in the single-layer ACs groups and single-layer BMECs groups, respectively. However, the difference was $0.4-0.5 \mathrm{~cm}$ after culturing for $4 \mathrm{~h}$ in the co-culture model, indicating that water molecules can no longer pass freely, the compact structure could withstand a strong osmotic pressure and the barrier function had been basically formed.

\section{Permeability of HRP}

If the HRP reacts with the substrates (TMB \& $\mathrm{H}_{2} \mathrm{O}_{2}$ ), it will result in a color development. The linear relationship between the concentrations (mol/L) of $D_{450}$ and HRP at $450 \mathrm{~nm}$ is $D=0.1617 C+0.0097, R^{2}=0.9983$, respectively. After $4 \mathrm{~h}$, the permeability of single-layer BMECs was $1.8 \%$, and that of the co-culture model was merely $0.23 \%$. The difference permeability of HRP was greater between the single-layer BMECs group and the co-culture model in the time that followed (Fig. 5). After 24 h, it was in accordance with the results of the liquid surface leakage test. 


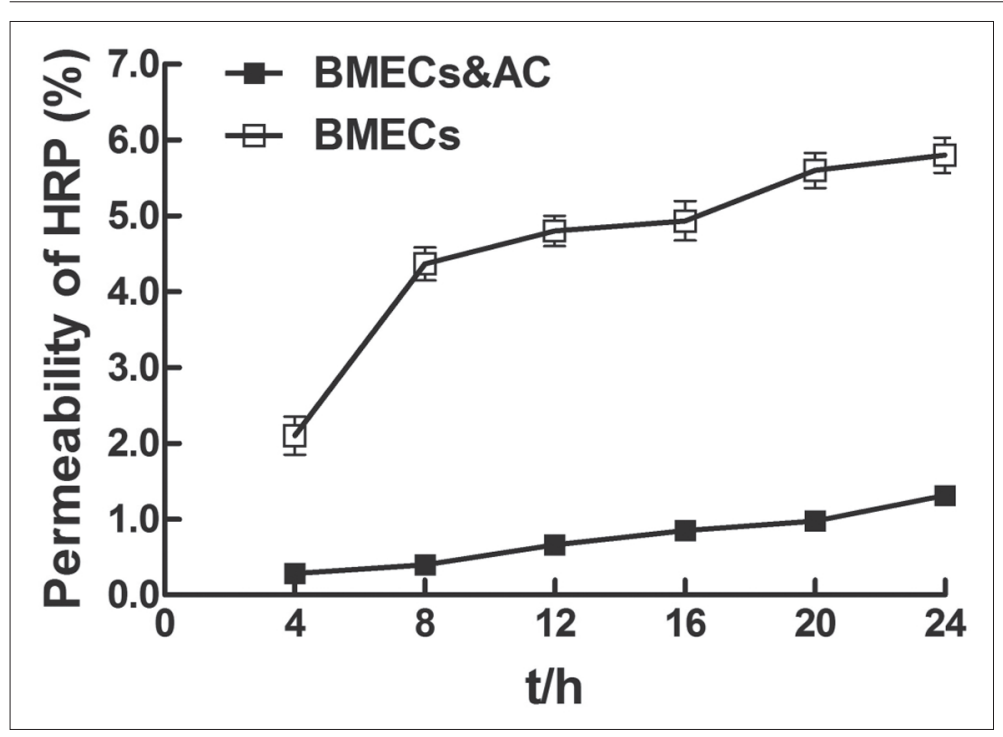

Fig 5. Co-culture model and single-layer BMECs group permeability assay for HRP One-way ANOVA was used for statistical analysis, $n=3,{ }^{* *} P<0.05$, Error bars: SD

\section{DISCUSSION}

The BBB is highly specialized to allow precise control over the substances that leave or enter the brain and maintain the stability of the CNS and normal function of neurons through selective permeation. The monocultures of brain endothelial cells forming BBB models has become an important tool in the early research of BBB [28]; however, it loses some important properties in contrast with in vivo models, such as increasing the permeability of tight junction and low-level expression of specific antigen ${ }^{[26]}$. With the development of research, some investigators found that ACs are necessary for the BBB and play an important fundamental role in the development, maintenance, and regulation of the $\mathrm{BBB}$ in vivo ${ }^{[29,300}$. In many co-culture models, BMECs and ACs come from different animal species. Although there are no unified and recognized standards, it seems the best choice would be to choose same-genus BMECs and primitive ACs in the construction of BBB models in vitro. In view of BMECs and $A C s$ in the BBB are not in direct contact, but have a space between them. We used Transwell chambers as the carrier for the co-culture of BMECs and ACs, and in this way, the functional characteristics of the cell function can be better maintained.

\section{Primary Culture of Cells}

Sheep BMECs and ACs were simultaneously isolated according to some previously described cell culture protocols ${ }^{[19,20]}$, with some modifications. The pia mater and surface vessels that were carefully removed from the forebrains contribute to purifying the BMECs and prevent fibroblasts from polluting the endothelial cells. Great vessels and tissue mass could be efficiently/effectively removed through tissue homogenate, density gradient centrifugation, and cell strainers. Enzyme digestion combined with gradient centrifugation was used to separate and purify the capillaries in the brain. Cerebral microvascular tissue was completely separated from the brain by digestion with collagenase II and trypsin. To ensure endothelial cell vitality, the second digestion time of 10-15 min must be used. Moreover, BMECs are difficult to culture and demand a strict growth environment. Previous studies have also reported that supplementing growth factor frequently in the medium promotes cell proliferation and slows down the growth of hybrid cells ${ }^{[3]]}$, so we modified the DMEM/F12 culture medium by adding endothelial cell growth supplement (bFGF) to promote the growth of BMECs, and heparin sodium supplement to inhibit the growth of smooth muscle cells. Because of the weak adherence of BMECs ${ }^{[32]}$, we chose $1 \%$ collagen type IV to pre-coat the disposable culture bottles to facilitate adherence of capillaries and the growth of BMECs. But for $\mathrm{ACs}$, the process is relatively simple. Because of the differential adhesion among fibroblasts, BMECs and ACs, we used a fresh cell culture bottle after $1 \mathrm{~h}$ of culture, and used the property to remove the fibroblasts and separate BMECs from available ACs. In addition, $\mathrm{AC}$ density is particularly important, $\mathrm{AC}$ growth is slow and may even cease ${ }^{[33]}$. It is, therefore, important to maintain high AC density during co-culture generation.

\section{Evaluation Index of the In Vitro BBB Model}

TEER measurement was established as the most reliable, convenient and non-destructive method to quantify the integrity of endothelial monolayer or co-cultured ${ }^{[34]}$. TEER dynamic measurements showed that resistance on either side of the Transwell increased with cell growth. At day 3, TEER of three groups were constant, indicative of a dense structure. The statistical analysis of data revealed the co-culture group had a significantly higher TEER than the single-layer BMEC or AC groups (Fig. 4) due to astrocyteendothelial interaction, which is important to maintain the barrier function of the BBB. This may because the coculture could promote the expression of tight junctions to make the structure more compact. When TEER values were constant, we designed a 4-h leakage test to further verify the density of the structure. After 3 days, the results of the 4-h leakage test showed a constant liquid level gap between the inner and outer layers of the Transwell chamber in the co-culture group and were consistent with TEER values, indicating that the co-culture group had formed a compact structure. However, the liquid level difference of single-layer groups had been a decrease of varying degrees. These results indicated that the larger the resistance, the denser the cell structure. We had also shown here that there was a significant difference in HRP 
permeability between the single-layer BMECs and the co-culture model. The results were consistent with those of the previous two experiments.

In the present study, we have constructed and characterized a BBB model consisting of the double co-culture of primary sheep BMECs and ACs, and we have shown the in vitro $\mathrm{BBB}$ model possesses in vivo BBB properties by detection of TEER, liquid surface leakage test and HRP permeability test. The co-culture model utilizes two different types of primary cells, therefore the method may pose a risk of low reproducibility in different laboratories. Preliminary results indicate that the co-culture model possess properties of the BBB in vivo and we will use it as a tool for studying the mechanisms of brain invasion mediated by internalins of LM.

\section{Competing Interests}

The authors declare that they have no competing interests.

\section{AcKnowledgements}

This research was supported by the funding from the National Natural Science Foundation of China(Grant No. 31260606) to J.Jiang.

\section{REFERENCES}

1. Hou H, Zhang G, Wang H, Gong H, Wang C, Zhang X: High matrix metalloproteinase-9 expression induces angiogenesis and basement membrane degradation in stroke-prone spontaneously hypertensive rats after cerebral infarction. Neural Regen Res, 9 (11): 1154-1162, 2014. DOI: 10.4103/1673-5374.135318

2.Abbott NJ, Rönnbäck L, Hansson E: Astrocyte-endothelial interactions at the blood-brain barrier. Nat Rev Neurosci, 7 (1): 41-53, 2006. DOI:10.1038/nrn1824

3. Wang Y, Wang N, Cai B, Wang GY, Li J, Piao XX: In vitro model of the blood-brain barrier established by co-culture of primary cerebral microvascular endothelial and astrocyte cells. Neural Regen Res, 10 (12): 2011-2017, 2015. DOI: 10.4103/1673-5374.172320

4. Parkes I, Chintawar S, Cader MZ: Neurovascular dysfunction in dementia-human cellular models and molecular mechanisms. Clin Sci, 132 (3): 399-418, 2018. DOI: 10.1042/CS20160720

5. Cecchelli R, Berezowski V, Lundquist S, Culot M, Renftel M, Dehouck MP, Fenart L: Modelling of the blood-brain barrier in drug discovery and development. Nat Rev Drug Discov, 6 (8): 650-661, 2007. DOI: 10.1038/ nrd2368

6. Abbott NJ, Dolman DE, Drndarski S, Fredriksson SM: An improved in vitro blood-brain barrier model: rat brain endothelial cells co-cultured with astrocytes. Methods Mol Biol, 814, 415-430, 2012. DOI: 10.1007/9781-61779-452-0_28

7. Wolff A, Antfolk M, Brodin B, Tenje M: In vitro blood-brain barrier models-an overview of established models and new microfluidic approaches. J Pharm Sci, 104 (9): 2727-2746, 2015. DOI: 10.1002/jps.24329

8. Abbott NJ: Dynamics of CNS barriers: Evolution, differentiation, and modulation. Cell Mol Neurobiol, 25 (1): 5-23, 2005. DOI: 10.1007/s10571004-1374-y

9. Haseloff RF, Blasig IE, Bauer HC, Bauer H: In search of the astrocytic factor(s) modulating blood-brain barrier functions in brain capillary endothelial cells in vitro. Cell Mol Neurobiol, 25 (1): 25-39, 2005. DOI: $10.1007 / \mathrm{s} 10571-004-1375-x$
10. Tao-Cheng JH, Nagy Z, Brightman MW: Tight junctions of brain endothelium in vitro are enhanced by astroglia. J Neurosci, 7 (10): $3293-$ 3299, 1987

11. Liu C, Chen K, Lu Y, Fang, Z, Yu GR: Catalpol provides a protective effect on fibrillary $A \beta 1-42$-induced barrier disruption in an in vitro model of the blood-brain barrier. Phytother Res. 1-9, 2018. DOI: 10.1002/ptr.6043 12. Jeong S, Kim S, Buonocore J, Park J, Welsh CJ, Li J, Han A: A three-dimensional arrayed microfluidic blood-brain barrier model with integrated electrical sensor array. IEEE Trans Biomed Eng, 65 (2): 431-439, 2018. DOI: 10.1109/TBME.2017.2773463

13. Gründler T, Quednau N, Stump C, Orian-Rousseau V, Ishikawa $H$, Wolburg H, Schroten H, Tenenbaum T, Schwerk C: The surface proteins InIA and InIB are interdependently required for polar basolateral invasion by Listeria monocytogenes in a human model of the blood-cerebrospinal fluid barrier. Microbes Infect, 15 (4): 291-301, 2013. DOI: 10.1016/j. micinf.2012.12.005

14. Cossart P, Lebreton A: A trip in the "New Microbiology" with the bacterial pathogen Listeria monocytogenes. FEBS Lett, 588 (15): 24372445, 2014. DOI: 10.1016/j.febslet.2014.05.051

15. Shimojima Y, Ida M, Nakama A, Nishino Y, Fukui R, Kuroda S, Hirai A, Kai A, Sadamasu K: Prevalence and contamination levels of Listeria monocytogenes in ready-to-eat foods in Tokyo, Japan. J Vet Med Sci, 78 (7): 1183-1187, 2016. DOI:10.1292/jvms.15-0708

16. Pagliano P, Ascione T, Boccia G, De Caro F, Esposito S: Listeria monocytogenes meningitis in the elderly: Epidemiological, clinical and therapeutic findings. Infez Med, 24 (2): 105-111, 2016.

17. Seveau S, Pizarro-Cerda J, Cossart P: Molecular mechanisms exploited by Listeria monocytogenes during host cell invasion. Microbes Infect, 9 (10): 1167-1175, 2007. DOI: 10.1016/j.micinf.2007.05.004

18. Gelbíčová T, Pantůček R, Karpíšková R: Virulence factors and resistance to antimicrobials in Listeria monocytogenes serotype 1/2c isolated from food. J Appl Microbiol, 121 (2): 569-576, 2016. DOI: 10.1111/jam.13191

19. Bernas MJ, Cardoso FL, Daley SK, Weinand ME, Campos AR, Ferreira AJG, Hoying JB, Witte MH, Brites D, Persidsky Y, Ramirez SH, Brito MA: Establishment of primary cultures of human brain microvascular endothelial cells to provide an in vitro cellular model of the blood-brain barrier. Nat Protoc, 5 (7): 1265-1272, 2010. DOI: 10.1038/ nprot.2010.76

20. Bobilya DJ: Isolation and Cultivation of Porcine Astrocytes. In, Milner $\mathrm{R}$ (Ed): Astrocytes. Methods in Molecular Biology (Methods and Protocols), Vol 814, 12-135, Humana Press, 2012.

21. Wilhelm I, Fazakas C, Krizbai IA: In vitro models of the blood-brain barrier. Acta Neurobiol Exp, 71 (1): 113-128, 2011.

22. Pieper C, Pieloch P, Galla HJ: Pericytes support neutrophil transmigration via interleukin- 8 across a porcine co-culture model of the blood-brain barrier. Brain Res, 1524, 1-11, 2013. DOI: 10.1016/j. brainres.2013.05.047

23. Thomsen LB, Burkhart A, Moos T: A triple culture model of the blood-brain barrier using porcine brain endothelial cells, astrocytes and pericytes. PLoS One, 10 (8): e0134765, 2015. DOI: 10.1371/journal. pone.0134765

24. Steiner O, Coisne C, Engelhardt B, Lyck, R: Comparison of immortalized bEnd5 and primary mouse brain microvascular endothelial cells as in vitro blood-brain barrier models for the study of T cell extravasation. J Cereb Blood Flow Metab, 31 (1): 315-327, 2011. DOI: 10.1038/jcbfm.2010.96

25. Burek M, Salvador E, Förster CY: Generation of an immortalized murine brain microvascular endothelial cell line as an in vitro blood brain barrier model. J Vis Exp, 66, e4022, 2012. DOI: 10.3791/4022

26. Wuest DM, Lee KH: Optimization of endothelial cell growth in a murine in vitro blood-brain barrier model. Biotechnol J, 7 (3): 409-417, 2012. DOI: 10.1002/biot.201100189

27. Hanada S, Fujioka K, Inoue Y, Kanaya F, Manome Y, Yamamoto K: Cell-based in vitro blood-brain barrier model can rapidly evaluate nanoparticles' brain permeability in association with particle size and surface modification. Int J Mol Sci, 15 (2): 1812-1825, 2014. DOI: 10.3390/ ijms15021812 
28. Kim KS: Microbial translocation of the blood-brain barrier. Int $\mathrm{J}$ Parasitol, 36 (5): 607-614, 2006. DOI: 10.1016/j.ijpara.2006.01.013

29. Rapôso C, Odorissi PAM, Oliveira ALR, Aoyama H, Ferreira CV, Verinaud L, Fontana K, Ruela-de-Sousa RR, da Cruz-Höfling MA: Effect of Phoneutria nigriventer, venom on the expression of junctional protein and P-gp efflux pump function in the blood-brain barrier. Neurochem Res, 37 (9): 1967-1981, 2012. DOI: 10.1007/s11064-012-0817-y

30. Kaisar MA, Sajja RK, Prasad, S, Abhyankar VV, Liles T, Cucullo L: New experimental models of the blood-brain barrier for CNS drug discovery. Expert Opin Drug Discov, 12 (1): 89-103, 2017. DOI: 10.1080/17460441.2017.1253676

31. Gaillard PJ, Voorwinden LH, Nielsen JL, Ivanov A, Atsumi $\mathbf{R}_{,}$ Engman H, Ringbom C, de Boer AG, Breimer DD: Establishment and functional characterization of an in vitro model of the blood-brain barrier, comprising a co-culture of brain capillary endothelial cells and astrocytes. Eur J Pharm Sci, 12 (3): 215-222, 2001. DOI: 10.1016/S09280987(00)00123-8

32. Schroeter ML, Müller S, Lindenau J, Wiesner B, Hanisch UK, Wolf G, Blasig IE: Astrocytes induce manganese superoxide dismutase in brain capillary endothelial cells. Neuroreport, 12 (11): 2513-2517, 2001. DOI: 10.1097/00001756-200108080-00045

33. Scism JL, Laska DA, Horn JW, Gimple JL, Pratt SE, Shepard RL, Dantzig AH, Wrighton SA: Evaluation of an in vitro, co-culture model for the blood-brain barrier: Comparison of human umbilical vein endothelial cells (ECV304) and rat glioma cells (C6) from two commercial sources. In Vitro Cell Dev Biol Anim, 35 (10): 580-592, 1999. DOI: 10.1007/s11626-9990096-3

34. Tian $X$, Brookes $\mathbf{O}$, Battaglia G: Pericytes from mesenchymal stem cells as a model for the blood-brain barrier. Sci Rep, 7, 39676, 2017. DOI: 10.1038/srep39676 